ИСТОРИЈСКИ ЧАСОПИС, књ. LXVII (2018) стр. 287-308

THE HISTORICAL REVIEW, vol. LXVII (2018) pp. 287-308

УДК: 930.85(497.11):929 Ровински, П.

\author{
Андрей Л. ШЕМЯКИН \\ Институт славяноведения \\ Российской академии наук \\ Москва \\ Россия
}

\title{
СЕРБСКИЕ СОЧИНЕНИЯ П. А. РОВИНСКОГО (ПЕРВИЧНОЕ ОСМЫСЛЕНИЕ И ПЕРСПЕКТИВЫ ИССЛЕДОВАНИЯ)
}

\begin{abstract}
Aбстракm: В статье показано, что сербские сочинения П.А. Ровинского, до сих пор малоизученные (в отличие от его мощного черногорского научного корпуса), дают возможность рассмотреть изнутри особенности менталитета сербского традиционного общества и усилить общий вывод, сделанный автором статьи ранее: за фасадом европейских новаций, в виде «стандартного» набора атрибутов либерально-буржуазного государственного устройства, скрывались устойчивые структуры и навыки традиционного общества; именно они определяли уклад жизни и поведения не только простого селяка, но и большей части сербской элиты. Осознание этой парадигмы «другой модернизации» (заметно отличавшейся от опыта пути в современность государств ее «первой волны»), в рамках которой традиционное общество, мимикрируя, отмалчиваясь или бунтуя, сопротивлялось переменам и воспроизводилось в новейших, но чисто «фанерных» декорациях, дает нам в руки мощные козыри для полемики с характерной для современной национальной историографии мифологией «европейского выбора», якобы сделанного Сербией еще в конце XIX в.

Ключевые слова: П.А. Ровинский, Сербия, Европа, менталитет сербского традиционного общества, имагология, модернизация.
\end{abstract}

«Руси нас Србе никако не разумевају. Зато бива толико незгода и за нас и за њих. Неразумевање је то отуда ито о Србима нема још списа, из којих би се могла видети душа Србинова у сваком погледу» (Милан Милићевић. Дневник) 
Павел Аполлонович Ровинский (1831-1916), как и многие другие представители его поколения «шестидесятников», был многогранно талантлив: выдающийся славист, вошедший в историю науки своим фундаментальным трудом по истории и этнографии Черногории ${ }^{1}$; проницательный журналист; незаурядный педагог; и еще - неутомимый путешественник, объехавший в буквальном смысле слова полмира, от США до Китая, и проведший около тридцати лет на Балканах.

Он родился в Саратовской губернии в дворянской семье. Получил блестящее образование, окончив в 1848 г. Саратовскую гимназию (где сдружился с А.Н. Пыпиным и Н.Г. Чернышевским), а затем с золотой медалью и историко-филологический факультет Казанского университета. Несмотря на то, что тот считался «одним из самых скромных провинциальных университетов»², в нем бывали и исключения - кафедру славянских наречий держал известный ученый В.И. Григорович, только что вернувшийся из путешествия по славянским странам. Ему и был обязан Ровинский своим интересом к славистике ${ }^{3} .$. По получении диплома он перебрался в Петербург, где стал заниматься изучением истории славян и журналистикой.

По своим идейным воззрениям Ровинский был последователем Чернышевского, принимал участие в революционном движении, печатался в демократических изданиях того времени - журнале «Современник» и газете «Очерки». Являлся активным членом тайного общества «Земля и воля» $(1862-1863)^{4}$.

Именно это обстоятельство помешало ему в 1862 г. совершить научную поездку за границу, настоятельно рекомендованную В.И. Григоровичем - разрешения на выезд Ровинский так и не получил, поскольку «находился в сношениях с лицами, имеющими злонамеренное предприятие» ${ }^{5}$. А, между тем, еще не ведая об окончательном вердикте властей, он разработал «План путешествия по славянским землям»,

1 П. А. Ровинский, Черногория в ее прошлом и настоящем, Т. I, Санкт-Петербург 1888; T. II, Ч. 1, Санкт-Петербург 1897; T. II, Ч. 2, Санкт-Петербург 1901; T. III, Петроград 1915.

2 А. Н. Пыпин, Мои заметки, Москва 1910, 30.

3 Там же, 38; М. Г. Долобко, П. А. Ровинский, Журнал Министерства Народного Просвещения, Кн. 7 (1916) 17.

4 См.: Л. Ф. Пантелеев, Воспоминания, Москва 1958; В. Я. Гросул, Российские револючиионеры в Юго-Восточной Европе, Кишинев 1973; В. Н. Юдин, Сподвижник Чернышенвского, Волгоград 1983.

5 Л. А. Котлярская, М. М. Фрейденберг, Из истории отечественной славистики: П.А. Ровинский в Черногории, Калинин 1988, 20. 
в котором писал: «Я избираю южнославянские земли». Главной же познавательной целью при посещении южных славян объявлялось намерение «обращать внимание на их внутреннюю жизнь, на историю быта и просвещения», причем «изучение современности должно служить пояснением и дополнением истории» ${ }^{6}$. Но исполнить свой план Ровинскому удалось только шесть лет спустя, когда у него наконецто появилась возможность отправиться к южным славянам - на сей раз в качестве корреспондента солидной столичной газеты «СанктПетербургские ведомости».

Местом его пребывания была избрана Сербия, и это не случайно. Мирный вывод турецких гарнизонов из всех крепостей Княжества в 1867 г., складывание Балканского союза и подготовка общего восстания против турок привлекали повышенное внимание русской публики. «То было особенное время, - вспоминал позднее сам Ровинский. - На Сербии сосредотачивались желания и надежды всего юга славянства. Одни полагали в ней свое спасение; другие ее боялись» ${ }^{7}$.

Итак, в начале марта 1868 г. он прибыл в Белград и оставался в Сербии до июля следующего года. Летом 1869 г., через Новый Сад, Вуковар и Осиек, отправился в Загреб, а в сентябре переехал в Швейцарию. После длительного перерыва, летом-осенью 1878 г., он провел корреспондентом в Сербии еще несколько месяцев. Это была его вторая и последняя поездка туда... В результате путешествий Ровинского по Сербии оформился целый корпус его сербских сочинений, состоявший из четырех путевых очерков и четырех статей ${ }^{8}$. Именно о нем и его значении для исследования

6 Цит. по: В. Н. Юдин, Сподвижник Чернышевского, 81.

7 П. А. Ровинский, Болгарский хайдук Панайот и его записки, Отечественные записки, Кн. 8 (1878) 349, 351.

8 См. очерки: П. А. Ровинский, Два месяца в Сербии (из путевых воспоминаний), Вестник Европы, Кн. 11 (1868) 364-386; Он же, Белград. Его устройство и общественная жизнь. Из записок путешественника, I-II, Вестник Европы, Кн. 4 (1870) 530-579; Кн. 5, 132-188; Он же, Воспоминания из путешествия по Сербии в 1868 г., Вестник Европы, Кн. 11 (1875) 5-34; Кн. 12, 699-725; Он же, Сербская Морава, Вестник Европы, Кн. 4 (1876) 517-558. И статьи - П. А. Ровинский, Наши отношения к сербам (поучение из прошлого и настоящего), Древняя и новая Россия, Т. I, № 2 (1877) 174-191; Он же, Россия и славяне Балканского полуострова, Древняя и новая Россия, Т. I, № 2 (1878) 144-169; Он же, Битва у Каменицы близ Ниша (в мае 1809 г.): эпизод из истории войн за освобождение, Древняя и новая Россия, Т. II, № 5 (1878) 53-63; Он же, Болгарский хайдук Панайот и его записки, 345-388. Общий объем сербских текстов П. А. Ровинского составляет более 30 печатных листов. 
глобальной темы: «Менталитет сербского традиционного общества и его эволюиия в условиях воздействия европейских идей и институтов, т.е. в процессе модернизащии Сербии», пойдет речь в настоящей статье.

Уже упоминалось, что, как славист, П.А. Ровинский прославился многотомным трудом о Черногории. Его же работы о Сербии и сербах, в своей совокупности, еще не стали предметом пристального внимания ученых, оставаясь в тени. Хотя знакомство с ним и некоторыми его текстами привело как современников, так и позднейших исследователей к солидарной оценке их «качества». Всего несколько примеров. Очевидец, крупный русский славист (в 1878-1882 гг. - профессор Великой школы в Белграде), П.А. Кулаковский: «Ровинский - действительно прекрасный знаток южных славян, очень умный и образованный человек <..>. Он был и профессором, и писал уже много о Сербии, и долго жил здесь и изучал народ и страну» ${ }^{9}$. И далее: «Этот человек оригинал, но замечательно знает и дела, и людей во всем сербском племени» ${ }^{10}$. Другой современник, сербский друг и тезка, Павле Михайлович: «Ровинский был ученым человеком, полным энергии и воли. Он всю Сербию исходил пешком и на этом пути провел много времени» ${ }^{11}$. Отечественные историки: С.Ю. Иванов - в своих трудах Ровинский «высказывает идеи такой степени зрелости, которая приближается к уровню современных исследований» ${ }^{2}$; Л.А. Котлярская и М.М. Фрейденберг: в поздних публикациях (указанных в примечании 8 статьях 1877-1878 гг.) - «более глубоких, продуманных и основательных» - автор размышляет не столько о реальных событиях, сколько о психологии целого народа, или отдельной его части. Он «как бы поднимается над конкретной действительностью <..>, переключаясь на анализ более глубоких пластов народной жизни». Такие его страницы, уверяют ученые, «могут войти в любую хрестоматию по историии Сербии XIX в.»> ${ }^{13}$, с чем мы полностью солидарны, также полагая сербский корпус

9 П. А. Кулаковский - И. С. Аксакову, Белград, 14 февраля 1879 г., Русские о Сербии и сербах, Т. II (архивные свидетельства), Сост. А. Л. Шемякин, Москва 2014, 121-122.

${ }^{10}$ П. А. Кулаковский - И. С. Аксакову, Белград, 14 февраля 1880 г., Там же, 160.

${ }^{11}$ П. Михајловић, Дневници, прир. Ј. Милановић, Београд 2010, 376.

${ }^{12}$ С. Ю. Иванов, П. А. Ровинский о сербском народе (Опьт этнопсихологической характеристики), П. А. Ровинский (1831-1916) и его время, Калинин 1988, 56. 13 Л. А. Котлярская, М. М. Фрейденберг, Из истории отечественной славистики: П. А. Ровинский в Черногории, 24. 
Павла Аполлоновича «подлинной находкой для всякого исследователя социальной и культурной истории Сербии» ${ }^{14}$. Наконец, сербская исследовательница Латинка Перович: «Трудно найти иностранного автора, писавшего о Сербии во второй половине XIX в., который не только лучше Ровинского разбирался бы в менталитете сербского народа, но и вообще писал о нем» ${ }^{15}$. К этому добавим, что опубликованные в «Вестнике Европы» четыре очерка П.А. Ровинского о Сербии вышли отдельным изданием в переводе на сербский язык - под редакцией и с предисловием той же Л. Перович ${ }^{16}$, вызвав у сербов неподдельный интерес: тираж был раскуплен всего за несколько месяцев. В чем, думается, нет ничего удивительного...

Занимаясь составлением первых двух томов антологии «Русские о Сербии и сербах» ${ }^{17}$, мы, естественно не могли обойти вниманием соответствующие работы Ровинского - в первый том серии вошло несколько обширно откомментированных фрагментов из его записок о путешествиях по Сербии в $1868-1869$ гг. ${ }^{18}$, а во второй - оригиналы четырех писем А.Н. Пыпину, тогда же посланных из Белграда ${ }^{19}$. Кроме того, отрывок из очерка Ровинского о сербской столице воспроизведен нами в российском историческом журнале «Родина» ${ }^{20}$. Готовя эти материалы к печати, мы пришли в выводу о настоятельной необходимости публикации всего сербского наследия русского слависта, причем - в виде отдельного, завершающего антологию (третьего) тома. В него, помимо всех авторских текстов, должны войти развернутый научный комментарий (в силу «неугомонности» и дотошности Павла Аполлоновича [«Я старался обозреть все, что возможно, не хотел пропустить ни одного предмета, как бы он ни был далек от моих личных целей и воззрений, стараясь передать каждое явление со всевозможной точностью» ${ }^{21}$ ], его описания страны пребывания - предельно информативны, «населены» многочисленными

${ }^{14}$ См.: А. Л. Шемякин, «Мир детства» сербов в путевых записках П.А. Ровинского, Славянский альманах, Москва 2004, 72-93.

${ }^{15}$ L. Perović, Drugi o nama, Ljudi, događaji i knjige / L. Perović, Beograd 2000, 163.

${ }^{16}$ П. А. Ровински, Записи о Србији (1868-1869), прир. Л. Перовић, Нови Сад 1994. См. также: Л. Перовић, П. А. Ровински о Србији 1868. године, Српско-руске револуционарне везе / Л. Перовић, Београд 1993, 41-46.

${ }^{17}$ См.: Русские о Сербии и сербах, Т. I, (письма, статьи, мемуары), Сост. А. Л. Шемякин, Санкт-Петербург 2016; T. II, (архивные свидетельства).

${ }^{18}$ Там же, T. I, 38-118.

${ }^{19}$ Там же, T. II, 55-63.

${ }^{20}$ А. Л. Шемякин, Павел Ровинский. Сербская физиономия Белграда, Родина, № 9 (Москва 2006) 54-58.

${ }^{21}$ П. А. Ровинский, Два месяцุа в Сербии (из путевых воспоминаний), 374. 
персонажами, требующими биографических справок, и густо пересыпаны сербизмами); а также, по примеру первых двух томов, монографическая студия-заключение - это позволит значительно обогатить форму и жанр «привычного» сборника материалов, на что в свое время, говоря о томе первом, уже указала И.И. Лещиловская: «Это издание, соединившее в себе публикацию документов и исследование, разрушило стереотипность исторических работ и явило собой новый тип исторического труда» ${ }^{22} \ldots$

$$
* \quad * \quad *
$$

Соображения, подвигшие нас к выделению всех работ П.А. Ровинского в единый отдельный том антологии «Русские о Сербии и сербах», следующие.

Подготовка к изданию его «собрания сочинений» о Сербии видится тем значительнее, если вспомнить, что главная ценность любых «сторонних» наблюдений заключается в том, что зарубежный «пилигрим» обращает внимание на непривычные для него, но вполне ординарные для местных жителей стороны жизни. Эти рутинные, с точки зрения обыденного опыта, детали, как правило, не попадают во внутренние источники («Описания иностранцев часто могут открывать вещи, неизвестные туземцам, и всегда помогают им видеть свою жизнь с той именно стороны, которая им недоступна» ${ }^{23}$ ), каких и так не слишком много, ведь «традиционное общество» исторически относится в основном к дописьменной культуре; и, следовательно, значение свидетельств русского очевидца (в которых явно прослеживается попытка синтетического осмысления увиденного) при его изучении неизмеримо возрастает. Что подтверждали и сами сербы. К примеру, известный писатель и этнолог Милан Миличевич, чье высказывание мы вынесли в эпиграф, ознакомившись с очерком Ровинского о Белграде, записал в дневнике: «Это правда, что человек привыкает к своим недостаткам и не может их видеть в той мере, как иностранец» ${ }^{24}$.

Кроме того, взятая в отдельности, каждая работа П.А. Ровинского имеет значение всего лишь локальной иллюстрации, но рассмотренные в комплексе, они приобретают характер репрезентативного источника,

22 И. И. Лещиловская, Сербская культура ХVIII-XX веков в послевоенной советской и современной российской историографии, Россия и Сербия глазами историков двух стран. Санкт-Петербург 2010, 37.

${ }^{23}$ П. А. Ровинский, Два месяцุа в Сербии (из путевых воспоминаний), Русские о Сербии и сербах, Т. I, 39.

${ }^{24}$ М. Милићевић, Дневник, I, (1869-1872), прир. П. Крестић, Београд 2011, 331. 
чей анализ дает возможность для широких обобщений, объемно демонстрируя срез жизни, поведения и представлений сербов на начальном этапе модернизации их страны (конец 1860-х гг.), т.е. фиксируя ее отправную точку.

При этом, следует особо подчеркнуть значимость впечатлений именно русского наблюдателя, коего культурная близость предохраняла от сильных искажений сербского колорита. Ведь «русский взгляд» на сербов, основанный на схожих ценностных и социокультурных посылках, порождаемых этнической близостью и конфессиональным единством, проникал в духовные скрепы сербского традиционного общества значительно глубже, чем «взгляд европейский», в фокусе которого находилась имманентно присущая Западу «презумпция цивилизационного превосходства» ${ }^{25}$, удачно раскрытая в дефиниции Марии Тодоровой: «Былое аристократическое неприятие эгалитарных крестьянских сообществ сменилось предрассудками городской (буржуазной и рациональной) культуры в отношении того, что считалось суеверной иррациональной и отсталой - руральной традицией Балкан, единственной ценностью которой признавалось, что в глазах Европы она являла собой этнографический музей под открытым небом» ${ }^{26}$. Не случайно поэтому, будучи русским человеком, П.А. Ровинский воспринимал Сербию и сербов как своих: «То, что недоступно в Сербии для каждого иностранца, вполне открыто для нас. Там вы чувствуете себя между своими, хотя и при другой обстановке» ${ }^{27}$. Что значит: «Если вы отбросите все несущественное, перед вами воскреснет родной тип малоросса». И далее, как резюме: «Характер и степень нашей культуры <..> более приближают нас к сербам, чем к остальным славянам» ${ }^{28}$.

Соответственно, описывая эту страну и народ, он не мог не сопоставлять все виденное с Россией («У меня постоянно идет сравнение $<\ldots>$ со своей родиной» $\left.{ }^{29}\right)$. И, надо сказать, что выстроенные им сопоставительные ряды весьма органичны, поскольку «мерка, по которой я оцениваю сербский народ, служит та самая, которую я применяю к России» ${ }^{30}$. Подобная органичность была чужда западному восприятию,

25 А. В. Гордон, Новое время как тип циивилизации, Москва 1996, 45.

${ }^{26}$ М. Тодорова, Имагинарни Балкан, Београд 1999, 196.

27 П. А. Ровинский, Наши отношения к сербам (поучение из прошлого и настоящеге), 187.

${ }^{28}$ Там же.

${ }^{29}$ Цит. по: Л. А., Котлярская, М. М. Фрейденберг, Из истории отечественной славистики: П. А. Ровинский в Черногории, 72.

${ }^{30}$ Там же. 
в основе которого, как уже говорилось, лежал стереотип о собственном превосходстве, чему соответствовало очевидное неравенство в подходах, т.е. две противоположные «мерки», характерные для всякого этноцентризма: одна - для себя, другая - для «туземцев».

Оно и понятно, ведь всякий западный автор, по точной оценке русского слависта, «ни на минуту не может забыть о том громадном расстоянии, которое находится между ним, человеком высшей цивилизации, и полуварварским сербом» ${ }^{31}$. И поэтому: «Иностранцы большее внимание обращают на памятники прошлого, на немую природу, а не на народ, войти в жизнь которого они не имеют ни охоты, ни способности. Они на все явления народной жизни смотрят издалека и свысока, схватывают их поверхностно и дают им толкование по своему вкусу или по своим субъективным воззрениям, а часто под сильным наитием какой-нибудь политической тенденции» ${ }^{32}$.

Другое дело - Ровинский, который прежде всего желал видеть «житье-бытье простого народа» ${ }^{33}$, причем в рамках системного подхода, пытаясь в ходе своих путешествий вычленить «нечто цельное, имееющее значение, общее и постоянное, а не случайное и временное» ${ }^{34}$. А иначе и быть не могло, учитывая его народнические взгляды. «Народник в политике, он был народником и в науке, - справедливо констатировал М. Г. Долобко. - Его тянул к себе народ, он инстинктивно стремился заглянуть в его душу, слиться с ним, сродниться. Отсюда его этнографические интересы, отсюда, после невозможности этнографических исследований на родной почве, перенесение их на почву ближайше родственного народа» ${ }^{35}$.

Важнейшим, наряду с отмеченным выше и по определению более глубоким проникновением в сербский характер, являлось то еще, что Ровинский наблюдал Сербию и сербов не проездом, но в течение длительного времени (около полутора лет в 1868-1869 гг.), т.е. непосредственно на месте. Различие в достоверности оценок этих двух категорий очевидцев прекрасно показал французский историк Альбер Мале, исполнявший в 1892-1894 гг. обязанности наставника юного сербского короля Александра Обреновича: «Внешний лак цивилизации - это то, что свидетельствует в пользу сербов и вводит в заблуждение

${ }^{31}$ П. А. Ровинский, Два месяияа в Сербии (из путевых воспоминаний), 379.

${ }^{32}$ Там же, 386.

${ }^{33}$ П. А. Ровинский, Воспоминания из путешествия по Сербии в 1867 году, 25.

${ }^{34}$ Цит. по: Л. А., Котлярская, М. М. Фрейденберг, Из истории отечественной славистики: П. А. Ровинский в Черногории, 39.

${ }^{35}$ М. Г. Долобко, П. А. Ровинский, 18. 
проезжего иностранца. Лак цивилизации, треснувший в тысяче мест, это то, что открывается человеку, имеющему возможность рассматривать все не спеша и в деталях, и делает из него врага изначального ложного образа» ${ }^{36}$. За полтора года пребывания в Сербском княжестве русский ученый мог себе позволить «рассматривать все не спеша»! Мало того, как признавался он сам: «Я не только наблюдал и изучал их (сербов. А.Ш.), но жил с ними и действовал» ${ }^{37}$, отчего степень достоверности его сведений может быть признана крайне высокой.

Действительно, Ровинский, как никто другой, помогает разобраться в их тонкой ментальной материи (поскольку цель его - «Выразить ту жизнь, тот внутренний процесс, который совершается под внешней оболочкой и придает предмету то особое выражение, которое мы называем характером или физиономией» ${ }^{38}$ [и что сегодня зовется как раз менталитетом]). Он исходил Сербию пешком, часто посещая самые отдаленные села и наблюдая за образом жизни и мироощущением населения во всех деталях, - как в Белграде, так и в глубинке. Отсюда (наряду с безупречным знанием предмета) и столь глубокое погружение в сербский характер, что вместе они приводили к «низким», но, увы, пророческим, истинам. «В истории этой страны нет почти ни одной отрадной страницы: одна война, одни междоусобия, сопровождаемые кровавыми сценами. История Сербии есть история ее мученичества» ${ }^{39},-$ эта неоднократно подтвержденная «в век нынешний и в век минувший» сквозная парадигма, которую хоть с ходу в эпиграф. Либо еще одно, не менее громкое «предвидение». Изучая сербский национальный характер и обнаружив среди его черт «самодовольство», следствием чего «является самонадеянность» и «самообольщение» ${ }^{40}$ («Не имея достаточного просвещения, но, сделавши некоторый успех настолько, что это заметно и постороннему, сербы преувеличивают свои успехи и приписывают их каким-то особенным способностям, которыми обладает их народ» ${ }^{41}$ ), или «самохвальство» и «исключительность сербская», как десятилетие спустя

36 А. Мале, Дневник са српског двора. 1892-1894., прев. и прир. Љ. Мирковић, Београд 1999, 204.

37 П. А. Ровинский, Черногория в ее прошлом и настоящем, T. I, IV.

${ }^{38}$ Он же, Два месяча в Сербии (из путевых воспоминаний), 378.

${ }^{39}$ Он же, Воспоминания из путешествия по Сербии в 1868 г., Русские о Сербии и сербах, Т. I, 76.

${ }^{40}$ П. А. Ровинский - А. Н. Пыпину, Белград, 20 апреля / 2 мая 1868 г., Русские о Сербии и сербах. Т. II, 56; П. А. Ровинский, Белград. Его устройство и общественная жизнь. Из записок путешественника, II; Там же, Т. I, 56, 68.

${ }^{41}$ Там же. 
назовет данную особенность П.А. Кулаковский ${ }^{42}$ (и что впоследствии, применительно к присущему своим соотечественникам «динарскому психологическому типу», подтвердит классик сербской историографии Слободан Йованович ${ }^{43}$ ), русский славист в письме А.Н. Пыпину сделал неутешительный прогноз, касательно возможных перспектив борьбы славянских народов с Османской империей: «Южные славяне победят турок, но побьются между собой» ${ }^{44}$, что и случилось во время Второй балканской (Межсоюзнической) войны в 1913 г. Ровно через 45 лет!..

Перед нами - следствие дисбаланса модернизации, вызванного преобладанием национального идеала («освобождение и объединение») над строительством гражданского общества, что совсем еще в зародыше и «подглядел» наблюдательный Ровинский («Во имя постоянно грозящей войны Сербия жертвует своими истинно человеческими интересами», ибо «на такой почве трудно ожидать, чтоб могли пустить глубокие корни гуманизм и гражданственность» ${ }^{45}$ ), словно экстраполируя зарождавшуюся на глазах диспропорцию на будущее. Ну, а там - в контексте империалистической горячки кануна Первой мировой войны национальная консолидация сербов обернулась мегаломанией великодержавия (истоки которой также вскрыл Ровинский, - в виде желания «целую Турцию разгромить и воссоздать царство Стефана Душана $\left.{ }^{46}\right)$, которая, столкнувшись с аналогичным явлением у соседки (Болгария заболела «самодовольством» в 1878 г., когда русские сформировали ее национальный идеал в Сан-Стефанских границах), не могла не спровоцировать лобовой конфликт за турецкое «наследие» на Балканах. Две непомерно раздутые «мегали-идеи», к тому же «обитающие» по соседству, не имели никакого шанса ужиться друг с другом...

Складывается впечатление, что на сербском примере П. А. Ровинский эмпирически предвосхитил теорию Ю.М. Лотмана о двух системах мышления - бинарной, в основе которой лежало желание «осуществить на практике неосуществимый идеал», и тернарной,

42 П. А. Кулаковский - Ап. А. Майкову, Белград, 18 октября 1880 г., Русские о Сербии и сербах, Т. II, 183.

${ }^{43}$ С. Јовановић, Један прилог за проучавање српског националног карактера, Сабрана дела С. Јовановића, Т. ХІІ, Из историје и књижевности, II, Београд 1991, 565. ${ }^{44}$ П. А. Ровинский - А. Н. Пыпину, Белград, 20 апреля / 2 мая 1868 г., 56.

45 П. А. Ровинский, Белград. Его устройство и общественная жизнь. Из записок путешественника, II, 74-75.

${ }^{46}$ Он же, Воспоминания из путешествия по Сербии в 1868 г., 77. 
что «стремится приспособить идеал к реальности» ${ }^{47}$. Кстати говоря, среди славян легко обнаруживаются носители обеих: сербы, болгары, черногорцы, хорваты, поляки - чехи, словенцы, словаки.

Должно особо подчеркнуть, что «обнаруженный» Павлом Аполлоновичем у сербов милитаристский настрой «санкционировался» снизу - многовековые конфликты с турками (производные от окраинного положения в составе Османской империи*) привели к формированию у них стойкого конфронтационного сознания, во многом определившего их дальнейшую историческую судьбу. Кроме того, идеологически оно подпитывалось «Косовским мифом» и растущей из поколения в поколение жаждой мести за катастрофу 1389 г., вследствие чего «героическое» начало закладывалось в поведенческий код населения с младых ногтей («Воинственный и геройский дух у сербов воспитывается с самого раннего детства $<\ldots>$. Воспитывается этот дух и отцами, заставляющими выучивать в виде катехизиса историю падения царства на Косовом поле, причем делают такие выводы, что Милошу Обиличу на вечные времена слава, Вуку Бранковичу проклятие, а турку и швабу нужно посекать головы» $\left.{ }^{48}\right)$. Образованные собеседники, признавая явный перекос такого воспитания, тем не менее объясняли Ровинскому его необходимость «Видите, в каком мы положении: мы должны из наших детей готовить вместо гуманных граждан диких солдат, потому что нам еще грозит война с турками и борьба с варварами, с которыми нужно мериться тем же оружием, каким пользуются и они против нас» ${ }^{49}$. Этот мотив грядущей войны и необходимости подготовки к ней сызмальства тиражировался на всех уровнях.

Важно и то, что «конфронтационное сознание» определяло специфику и внутригосударственной жизни в стране, органично экстраполируясь на отношение к другому в среде соотечественников,

${ }^{47}$ Ю. М. Лотман, Культура и взрыв, Семиосфера / Ю. М. Лотман, Санкт-Петербург 2000, 142.

* О влиянии географического положения славянских народов внутри Османской империи на формирование их менталитета см.: Особенности «новой» южнославянской государственности: Болгария, Сербия, Черногория, Королевство СХС в 1878-1921 гг. / Отв. ред. А.Л. Шемякин. Москва, 2016; Шемякин А.Л. Внутренние границы Османской империи и предпосылки модернизации в Болгарии и Сербии (последняя треть XIX - начало XX в. // Империи, граници, политики (XIX - началото на XX век). София, 2016. С. 287-297.

48 П. А. Ровинский, Сербская Морава, Русские о Сербии и сербах, Т. I, 109.

49 Он же, Белград. Его устройство и общественная жизнь. Из записок путешественника, II, 74-75. 
выбивавшемуся из традиционной системы ценностей и представлений. «Внешние турки», таким образом, могли плавно переходить в категорию «внутренних турок». А потому мір для сербов (как вовне, так и изнутри) был окрашен в черно-белые тона: свои - чужие, друзья - враги. Таким образом, сербы практически и не жили, постоянно воюя, либо ожидая войну, пребывая в никогда не спадавшем психологическом напряжении («На меня во время путешествия Сербия произвела впечатление полувоенного лагеря, стоящего на развалинах когда-то процветавшей страны, и еще не жившего вполне народа, которому еще предстоит жить и действовать ${ }^{50}$ ). В таких условиях в нем «создался какой-то специфический ритм и темп жизни, слабо приспособленный к современным методам труда и созидания» ${ }^{51}$. Оно и понятно: вместо естественного поступательного развития - всплески отчаянных усилий и относительно «мирные» паузы, заполненные не «органической работой», а новым ожиданием «национальной сатисфакции» и непримиримым внутриэлитарным конфликтом (те самые «междоусобия, сопровождаемые кровавыми сценами» [см. примечание 40]), то есть продолжением войны во время мира.

Соответственно, воспроизводимое исторической традицией и мифологией состояние внутренней мобилизованности народа, постоянная готовность к реализации «национального идеала» (добиться чего без военных мер было невозможно) вступали в противоречие с задачей формирования гражданского общества в стране, что, в свою очередь, не могло не сказаться на ходе и характере процесса ее модернизации, носившем однобокий и деформированный характер (все в Сербии «временное, неустановившееся, все в каком-то ожидании чего-то, вся она живет накануне [курсив П.А. Ровинского. - А.Ш.], вся в какомто воинственном настроении» ${ }^{52}$, стоя «вечно на карауле» ${ }^{53}$. «И такое состояние, - звучит рефрен, - мешает развитию страны в смысле гражданственности» $\left.{ }^{54}\right)$. Действительно, коллективный портрет серба второй половины XIX - начала XX в. вполне можно было бы подписать: Homo Militans, что значит - «человек вечной войны» или же «солдат по природе, по призванию» ${ }^{55}$, по дефинициям Павла Аполлоновича. Тем самым, он (одним из первых [профессор В.И. Ламанский в 1863 г. также

${ }^{50}$ Он же, Сербская Морава, 110.

${ }^{51}$ В. Дворниковић, Херојски тип и његове негативности, Борба идеја / В. Дворниковић, Београд 1995, 111.

52 П. А. Ровинский, Сербская Морава, 109.

53 Там же, 110.

54 Там же, 109.

55 П. А. Ровинский, Воспоминания из путешествия по Сербии в 1868 г., 77. 
окрестил сербов «народом более храбрым и воинственным, нежели трудолюбивым и промышленным» $\left.{ }^{56}\right]$ - сразу по завершении «процесса формирования стереотипного представления о них как о братском России народе, занявшего всю первую половину XIX в.» ${ }^{57}$ ) нащупал одну из важнейших ментальных струн сербского народа, что станет затем «героической вертикалью» всей его дальнейшей истории, вплоть до трагических событий рубежа XX-XXI вв.

$$
* * *
$$

Подготовка третьего тома антологии - финальный (по порядку, но не по значению) этап в рациональном познании затронутой сквозной проблемы: «Менталитет сербского традищионного общества...». Ведь если источники из первой книги использовались нами для исследования социокультурного контекста модернизационных процессов в Сербии (в рамках монографической статьи-заключения: «Традиционное общество и вызовы модернизации. Сербия последней трети XIX - начала XX в. глазами русских» ${ }^{58}$ ), то во второй - все внимание обращено на изучение специфики политической жизни в независимом Королевстве (т.е. политической составляющей «модернизации по-сербски»). Ее и завершает объемный аналитический очерк: «Особенности политического процесса в независимой Сербии (1878-1918) глазами русских» ${ }^{59}$. А третий том мы предполагаем закончить столь же обширным размышлением в озвученном выше ключе: «Человек вечной войны». И соответственно, из такого общего замысла вырастает вполне гармоничная исследовательская «триада»: заключение к первой части «Русских...» посвящено «человеку экономическому» в Сербии. Эпилог второй - повествует о «человеке политическом». А студия, завершающая третью, - даст понятие о «человеке воинственном». Каждая из этих ипостасей Серба важна сама по себе, но лишь взятые в совокупности, они позволят, как нам представляется, с немалой долей объективности, расшифровать код его менталитета, что, в свою очередь, даст возможность эмпирически нюансировать и усилить общий вывод (уже сделанный нами в результате

${ }^{56}$ В. И. Ламанский, Сербия и южно-славянские провинции Австрии, Русские о Сербии и сербах, Т. I, 28.

${ }^{57}$ М. В. Белов, На пути к славянскому братству, Открытие «братьев-славян»: русские путешественники на Балканах в первой половине XIX в., Сост. М. В. Белов, Санкт-Петербург 2008.

${ }^{58}$ Русские о Сербии и сербах, Т. I, 629-680.

${ }^{59}$ Русские о Сербии и сербах, Т. II, 551-627. 
реконструкции сербских социокультурных и политических реалий 2-й половины XIX - начала XX в.), который можно свести к следующему: за формально-институциональным фасадом европейских новаций, в виде «стандартного» набора атрибутов либерально-буржсуазного государственного устройства (конституции, парламентаризм, многопартийность, современные системы образования и воинской службы), скрывались устойчивые структуры и навыки традиционного общества; именно они определяли уклад жнизии и поведение не только простого селяка, но и большей части сербской элиты.

Осознание этой парадигмы «другой модернизации» (заметно отличавшейся от опыта пути в современность государств ее «первой волны»), в рамках которой традиционное общество, по выражению М. В. Белова, «мимикрируя, отмалчиваясь или бунтуя, сопротивлялось переменам и воспроизводилось в новейших, но „фанерных““* декорациях» ${ }^{60}$ («остатки туретчины и варварства, сверху только покрытые лоскутами цивилизации» ${ }^{61}$ ), способствует освобождению от сковывающих мысль умозрительных конструкций, предоставляя нам новые аргументы для полемики с носителями весьма характерной для новейшей национальной историографии мифологии «европейского выбора», якобы сделанного Сербией еще на рубеже XIX-XX вв. Ведь, целый ряд сербских авторов торжественно и в унисон провозглашает - после Майского переворота 1903 г., в ней «почти воплотилась британская двухпартийная модель демократии» ${ }^{62}$. Сама же политическая ситуация, сложившаяся в стране в предвоенное десятилетие, объявляется ими эпохой «аутентичной парламентской демократии», которая будто бы являлась «функциональной и полностью отвечала требованиям демократического правления» ${ }^{63}$.

\footnotetext{
* Имеется в виду, что «в результате ускоренного вестернизированного государственно-политического строительства получилось не новое здание, а его „фанерная“ имитация» (См.: Гришина Р.П., Шемякин А.Л. Судьба «балканских союзников» 1912-1913 гг. Взгляд из ХХІ столетия // Новая и новейшая история. Москва, 2013. № 4. С. 116).

${ }^{60}$ М. В. Белов, Рецензия на кн.: Человек на Балканах. Особенности «новой» южнославянской государственности: Болгария, Сербия, Черногория, Королевство СХС в 1878-1920 г2., Отв. ред. А. Л. Шемякин, Москва 2016, Славяноведение, № 1 (Москва 2017) 111.

${ }^{61}$ П. А. Ровинский, Белград. Его устройство и общественная жсизнь. Из записок путешественника, II, 55.

${ }^{62}$ Нова историја српског народа, ур. Д. Батаковић, Београд 2000, 188.

${ }_{63}$ Д. Батаковић, О парламентарној демократији у Србији 1903-1914. Странке, изборе, политичке слободе, Глас САНУ CDXX, Одељење историјских наука, књ. 16 (Београд 2012) 291, 407.
} 
Да и вообще: «Правление Петра Карагеоргиевича (1903-1914) запомнилось как „золотой век“ или „Периклова эра“ Сербии благодаря ускоренному политическому, национальному и культурному подъему, сопровождавшемуся ростом экономической самостоятельности. Причем ключом к успеху Сербии стала привлекательность ее демократического потенциала» ${ }^{64}$. А как же иначе, ведь «Сербия в начале XX в. была демократической страной, республикой (политией) свободных крестьян (выделено в оригинале. - А.Ш.). Для тех условий она имела передовую демократию, одну из самых развитых в Европе...» ${ }^{65}$.

В динамике подобных заявлений нами замечено, что с увеличением исторической дистанции между эпохой 1903-1914 гг. и временем, в каком живут ее исследователи, степень идеализации предмета изучения - в сравнении с оценками очевидцев (кому мы доверяем значительно больше) - неуклонно возрастает, что, впрочем, можно считать явлением типичным, поскольку мифический «золотой век» всегда необходим народам для самоутверждения и поддержания национального здравия, а сербам (с их моральными изломами и травмами последнего времени) - особенно. И потому причину безудержного восхваления ими своего политического прошлого не сложно объяснить теоретически. По словам В.А. Шнирельмана, «претензии на исторический приоритет некоторых $<\ldots>$ политических (государственность) достижений своих предков»- суть один из универсальных компонентов «этноцентристских версий прошедшего», которые создаются «в условиях серьезного этнополитического кризиса» ${ }^{66}$. Да, и вообще: «Миф о прошлом призван воспитать в людях самоуважение, сплотить их и наделить творческой энергией для его преодоления» ${ }^{67}$.

Очевидцы же событий не давали себя завлечь в сети формальноевропейских институций и принципов, пересаженных на сербскую почву и якобы прижившихся в ней. Противоречие между номинальным

64 Д. Батакович, Сербия накануне Первой мировой войны: внешние и внутренние вызовы, Накануне Великой войны: Россия и мир, Отв. ред. О. В. Петровская, Москва 2014, 45. См. также: M. Protić, Between democracy and populism. Political ideas of the Peopl's Radical party (The formative period: 1860's to 1903), Belgrade 2015, 152.

${ }^{65}$ С. Антонић, Демократија, Срби 1903-1914. Историја идеја, прир. М. Ковић, Београд 2015, 27.

${ }^{66}$ В. А. Шнирельман, Подделки и альтернативная история, Фальсификация исторических источников и конструирование этнократических мифов, Отв. ред. А. Е. Петров, В. А. Шнирельман, Москва 2011, 17-18.

${ }^{67} \mathrm{Oн} \mathrm{же,} \mathrm{Национальные} \mathrm{символь,} \mathrm{этноисторические} \mathrm{мифы} \mathrm{и} \mathrm{этнополитика,} \mathrm{Маке-}$ дония. Проблемы истории и культуры, Отв. ред. Р. П. Гришина, Москва 1999, 10-11. 
присутствием и реальным функционированием (то самое «воспроизводство традиционного общества в новейших, но фанерных декорациях») в виде чеканной формулы выразил видный интеллектуал и политик Коста Стоянович: «Демократия, парламентаризм, гражданские свободы, прогресс, культура и ряд других понятий, что составляют основу политического словаря нынешних балканцев, - суть слова и выражения, никак не укорененные в их мироощущении, однако, будучи „общепринятыми”, они призваны прикрыть жесткие подсознательные стереотипы, которые на самом деле только и мотивируют все их действия и поступки» ${ }^{68}$. Это было сказано в 1915 г., но еще в декабре 1868-го П.А. Ровинский описал А.Н. Пыпину тот же «симбиоз» квази-современной (modern) скорлупы и скрытого под нею глубоко традиционного ядра: «Трудно себе представить, до какой степени искажены нравы и понятия здешней, так называемой, интеллигенции. Мне кажется, нигде нет более резкого противоречия между внешней оболочкой, по которой человека можно принять за вполне цивилизованного европейца, и внутренней грубостью, доходящей до зверства и до совершенной неспособности понимать самые простые человеческие отношения, - как здесь» ${ }^{69}$.

Круг замкнулся - в «европейском», как полагают местные ученые, менталитете серба за полвека мало что изменилось. Причем, повторим еще раз, именно наш герой был одним из первых, кто вскрыл целый ряд родовых черт сербской коллективной «физиономии», носивших константный характер и подтвержденных затем не единожды. И соответственно, Ровинский укрепляет нас в еще одном синтетическом заключении: Реальная жсизнь независимой Сербии далеко не соответствовала тем "современным» формам, в какие ее облекают многие сербские историки, стремясь представить свою родину вполне сложивиимся «европейским государством»...

Замысел публикации сербских сочинений П.А. Ровинского актуален и по чисто мемориальным мотивам. В минувшем году исполнилось 185 лет со дня его рождения и 100 лет с момента кончины. А в 2018-2019 гг. «стукнет» ровно 150 лет со времени полуторагодичного пребывания русского слависта в Сербии. Кроме того, 2019 г. - это еще и юбилей первой нацииональной сербской конституции (1869), принятие которой можно считать началом политической модернизации страны, и процесс

${ }^{68}$ К. Стојановић, Слом и васкрсење Србије, прир. С. Турлаков, Београд 2012, 87. ${ }^{69}$ П. А. Ровинский - А. Н. Пыпину, Белград, 15 декабря 1868 г., Русские о Сербии и сербах, Т. II, 59. 
этот (точнее - его отправную точку) ученый застал непосредственно на месте, описав в путевых очерках, письмах и статьях.

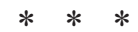

Итак, даже беглое ознакомление с сербскими текстами П.А. Ровинского наглядно показывает их мощный информационноаналитический потенциал; причем достоверность заключений автора лишь усиливается, имея в виду культуру его отношения к своему «ремеслу». Отчетливо понимая всю сложность поставленной задачи (связать воедино [в рамках системного подхода] детали и представить цельную «физиономию» сербов), он предъявил к себе ряд жестких научно-этических требований, следование которым полагал непременным условием ее разрешения, а именно - репрезентативность отбираемых для обобщения данных, объективность и отсутствие личных амбиций: «Я старался обозреть все, что возможно (данную фразу мы уже цитировали [см. примечание 22]. - A.Ш.), не хотел пропустить ни одного предмета, как бы он ни был далек от моих личных целей и воззрений». И далее, как резюме: «Отрешившись, насколько возможно, от всякой тенденции <..>, я смело могу сказать, что относился ко всему беспристрастно, стараясь передать каждое явление со всевозможной точностью» ${ }^{70}$.

Столь очевидная непредвзятость Ровинского в отношении всего им увиденного; вкупе с редким даром четко фиксировать свою цель, а также неугомонностью в желании достичь оную; при отсутствии так свойственного другим иностранцам этноцентризма, делают его свидетельства не только первоклассным источником для всякого специалиста по социокультурной истории Сербии, но и, быть может, тем сочинением (отсутствие коего, помнится, сильно печалило Милана Миличевича), где «би се могла видети душа Србинова у сваком погледу».

${ }^{70}$ П. А. Ровинский, Два месяцุа в Сербии, 374. 


\section{ЛИСТА РЕФЕРЕНЦИ - LIST OF REFERENCES}

\section{Извори - Primary Sources}

Кулаковский П. А. - И. С. Аксакову, Белград, 14 февраля 1879 г., Русские о Сербии и сербах, Т. II, (архивные свидетельства), Сост. А. Л. Шемякин, Москва 2014. [Kulakovskij P. A. - I. S. Aksakovu, Belgrad, 14 fevralja 1879 g., Russkie o Serbii i serbah, T. II, (arhivnie svidetel'stva), Sost. A. L. Šemjakin, Moskva 2014]

Кулаковский П. А. - И. С. Аксакову, Белград, 14 февраля 1880 г., Русские о Сербии и сербах, T. II. [Kulakovskij P. A. - I. S. Aksakovu, Belgrad, 14 fevralja 1880 g., Russkie o Serbii i serbah, T. II]

Кулаковский П. А. - Ап. А. Майкову, Белград, 18 октября 1880 г., Русские о Сербии и сербах, T. II. [Kulakovskij P. A. - Ap. A. Majkovu, Belgrad, 18 oktjabrja 1880 g., Russkie o Serbii i serbah, T. II]

Мале А., Дневник са српског двора. 1892-1894., прев. и прир. Љ. Мирковић, Београд 1999. [Male A., Dnevnik sa srpskog dvora. 1892-1894, prev. i prir. Lj. Mirković, Beograd 1999]

Милићевић М., Дневник, I, (1869-1872), прир. П. Крестић, Београд 2011. [Milićević M., Dnevnik, I, (1869-1872), prir. P. Krestić, Beograd 2011]

Михајловић П., Дневниии, прир. Ј. Милановић, Београд 2010. [Mihajlović P., Dnevnici, prir. J. Milanović, Beograd 2010]

Пыпин А. Н., Мои заметки, Москва 1910. [Pipin A. N., Moi zametki, Moskva 1910]

Ровинский П. А., Белград. Его устройство и общественная жизнь. Из записок путешественника, I-II, Вестник Европы, Кн. 4 (1870); Кн. 5 (1870) [Rovinskij P. A., Belgrad. Ego ustrojstvo i obščestvennaja žisni. Iz zapisok putešestvennika, I-II, Vestnik Evropi, Kn. 4 (1870); Kn. 5 (1970)]

Ровинский П. А., Воспоминания из путешествия по Сербии в 1868 г., Вестник Европы, Кн. 11 (1875) [Rovinskij P. A., Vospominanija iz putešestvija po Serbii v 1868 g., Vestnik Evropi, Kn. 11 (1875)]

Ровинский П. А., Воспоминания из путешествия по Сербии в 1868 г., Русские о Сербии и сербах, T. I [Rovinskij P. A., Воспоминания из путешествия по Сербии в 1868 г., Russkie o Serbii i serbah, T. I]

Ровинский П. А., Два месяиа в Сербии (из путевых воспоминаний), Вестник Европы, Кн. 11 (1876); Кн. 12 (1876) [Rovinskij P. A., Dva mesjaca v Serbii (iz putevih vospominanij), Vestnik Evropi, Kn. 11 (1876); Kn. 12 (1876)]

Ровинский П. А., Два месяиа в Сербии (из путевых воспоминаний), Русские о Сербии и сербах, T. I. [Rovinskij P. A., Dva mesjaca v Serbii (iz putevih vospominanij), Russkie o Serbii i serbah, T. I]

Ровински П. А., Записи о Србији (1868-1869), прир. Л. Перовић, Нови Сад 1994. [Rovinski P. A:, Zapisi o Srbiji (1868-1869), prir. L. Perović, Novi Sad 1994]

Ровинский П. А., Белград. Его устройство и общественная жизнь. Из записок путешественника, I-II, Вестник Европы, Кн. 4 (1870); Кн. 5 (1870) [Rovinskij P. A., Belgrad. Ego ustrojstvo i obščestvennaja žisni. Iz zapisok putešestvennika, I-II, Vestnik Evropi, Kn. 4 (1870); Kn. 5 (1970)] 
Ровинский П. А. - А. Н. Пыпину, Белград, 20 апреля / 2 мая 1868 г., Русские о Сербии и cepбax, T. II. [Rovinskij P. A. - A. N. Pipinu, Belgrad, 20 aprelja / 2 maja 1868 g., Russkie o Serbii i serbah, T. II]

Ровинский П. А. - А. Н. Пыпину, Белград, 15 декабря 1868 г., Русские о Сербии и сербах, T. II. [Rovinskij P. A. - A. N. Pipinu, Belgrad, 15 dekabrja 1868 g., Russkie o Serbii i serbah, T. II]

Русские о Сербии и сербах, Т. I, (письма, статьи, мемуары), Сост. А. Л. Шемякин, СанктПетербург 2016; T. II, (архивные свидетельства) [Russkie o Serbii i serbah, T. I, (pis'ma, stat'i, memuari), Sost. A. L. Šemjakin, Sankt-Peterburg 2016, T. II, (arhivnie svidetel'stva)]

\section{Литература - Secondary Works}

Perović L., Drugi o nama, Ljudi, događaji i knjige / L. Perović, Beograd 2000.

Protić M., Between democracy and populism. Political ideas of the Peopl's Radical party (The formative period: 1860's to 1903), Belgrade 2015.

Антонић С., Демократија, Срби 1903-1914. Историја идеја, прир. М. Ковић, Београд 2015. [Antonić S., Demokratija, Srbi 1903-1914. Istorija ideja, prir. M. Ković, Beograd 2015]

Батаковић Д., О парламентарној демократији у Србији 1903-1914. Странке, изборе, политичке слободе, Глас САНУ CDXX, Одељење историјских наука, књ. 16 (Београд 2012) [Bataković D., O parlamentarnoj demokratiji u Srbiji 1903-1914. Stranke, izbore, političke slobode, Glas SANU CDXX, Odeljenje istorijskih nauka, knj. 16 (Beograd 2012)]

Батакович Д., Сербия накануне Первой мировой войны: внешние и внутренние вызовы, Накануне Великой войны: Россия и мир, Отв. ред. О. В. Петровская, Москва 2014. [Bataković D., Serbija nakanune Pervoj mirovnoj vojni: vnešnie i vnutrennie vizovi, Nakanune Velikoj vojni: Rossija i mir, Otv. red. O. V. Petrovskaja, Moskva 2014]

Белов М. В., На пути к славянскому братству, Открытие «братьев-славян»: русские путешественники на Балканах в первой половине XIX в., Сост. М. В. Белов, СанктПетербург 2008. [Belov M. V., Na puti k slavjanskomu bratstvu, Otkritie «brat'ev-slavjan»: russkie puteštvenniki na Balkanah v pervoj polovine XIX v., Sost. M. V. Belov, Sankt-Peterburg 2008]

Белов М. В., Рещензия на кн.: Человек на Балканах. Особенности «новой» южнославянской государственности: Болгария, Сербия, Черногория, Королевство СХС в 1878-1920 г2., Отв. ред. А. Л. Шемякин, Москва 2016, Славяноведение, № 1 (Москва 2017) [Belov M. V., Recenzija na kn.: Čelovek na Balkanah. Osobennosti «novoj» južnoslavjanskoj gosudarstvennosti: Boglarija, Serbija, Černogorija, Korolevstvo SHS v 1878-1920 gg., Otv. red. A. L. Šemjakin, Moskva 2016, Slavjanovedenie, № 1 (Moskva 2017)]

Гордон А. В., Новое время как тип циивилиации, Москва 1996. [Gordon A. V., Novoe vremja kak tip civilizacii, Moslva 1996]

Гросул В. Я., Российские револючионеры в Юго-Восточной Европе, Кишинев 1973. [Grosul V. Ja., Rossijskie revoljucioneri v Jugo-Vostočnoj Evrope, Kišinev 1973]

Дворниковић В., Херојски тип и његове негативности, Борба идеја / В. Дворниковић, Београд 1995. [Dvorniković V., Herojski tip i njegove negativnosti, Borba ideja / V. Dvorniković, Beograd 1995]

Долобко М. Г., П. А. Ровинский, Журнал Министерства Народного Просвещения, Кн. 7 (1916) [Dolobko M. G., P. A. Rovinskij, Žurnal Ministerstva Narodnogo Prosveščenija, Kn. 7 (1916)]

Иванов С. Ю., П. А. Ровинский о сербском народе (Опыт этнопсихологической характеристики), П. А. Ровинский (1831-1916) и его время, Калинин 1988. [Ivanov 
S. J., P. A. Rovinskij o serbskom narode (Opit etnopsihologičeskoj haraktersitiki), P. A. Rovinskij (1831-1916) i ego vremja, Kalinin 1988]

Јовановић С., Један прилог за проучавање српског националног карактера, Сабрана дела С. Јовановића, Т. XII, Из историје и књижевности, II, Београд 1991. [Jovanović S., Jedan prilog za proučavanje srpskog nacionalnog karaktera, Sabrana dela S. Jovanovića, T. XII, Iz istorije i književnosti, II, Beograd 1991]

Юдин В. Н., Сподвижник Чернышенвского, Волгоград 1983. [Judin V. N., Spodvižnik Černišenvskogo, Volgograd 1983]

Котлярская Л. А., Фрейденберг М. М., Из истории отечественной славистики: П.А. Ровинский в Черногории, Калинин 1988. [Kotljarskaja L. A., Frejdenberg M. M., Iz istorii otečestvennoj slavistiki: P. A. Rovinskij v Vernogorii, Kalinin 1988]

Ламанский В. И., Сербия и южно-славянские провинции Австрии, Русские о Сербии и сербах, T. I. [Lamanskij V. I., Serbija i južno-slavjanskie provincii Avstrii, Russkie o Serbii i serbah, T. I]

Лещиловская И. И., Сербская культура XVIII-XX веков в послевоенной советской и современной российской историографии, Россия и Сербия глазами историков двух стран, Санкт-Петербург 2010. [Leštilovskaja I. I., Serbskaja kul'tura XVIII-XX vekov v poslevoennoj sovetskoj i sovremennoj rossijskoj istoriografii, Rossija i Serbija glazami istorikov dvuh stran, Sankt-Peterburg 2010]

Лотман Ю. М., Культура и взрыв, Семиосфера / Ю. М. Лотман, Санкт-Петербург 2000. [Lotman J. M., Kul'tura i vzriv, Semiosfera / J. M. Lotman, Sankt-Peterburg 2000]

Нова историја српског народа, ур. Д. Батаковић, Београд 2000. [Nova istorija srpskog naro$d a$, ur. D. Bataković, Beograd 2000]

Пантелеев Л. Ф., Воспоминания, Москва 1958. [Panteleev L. F., Vospominanija, Moskva 1958]

Перовић Л., П. А. Ровински о Србији 1868. године, Српско-руске револуционарне везе / Л. Перовић, Београд 1993. [Perović L., P. A. Rovinski o Srbiji 1868. godine, Srpsko-ruske revolucionarne veze / L. Perović, Beograd 1993]

Ровинский П. А., Битва у Камениць близ Ниша (в мае 1809 г.): эпизод из истории войн за освобождение, Древняя и новая Россия, Т. II, № 5 (1878) [Rovinskij P. A., Bitva u Kamenici bliz Niša (v mae 1809 g.): epizod iz istorii vojn za osvoboždenie, Drevnajaja i novaja Rosija, T. II, № 5 (1878)]

Ровинский П. А., Болгарский хайдук Панайот и его записки, Отечественные записки, Кн. 8 (1878) [Rovinskij P. A., Bolgarskij hajduk Panajot i ego zapski, Otečestvennie zapiski, Kn. 8 (1878)]

Ровинский П. А., Наши отношения к сербам (поучение из прошлого и настоящего), Древняя и новая Россия, Т. I, № 2 (1877) [Rovinskij P. A., Naši otnošenija k serbam (poučenie iz prošlogo i nastojaščego), Drevnajaja i novaja Rossija, T. I, № 2 (1877)]

Ровинский П. А., Россия и славяне Балканского полуострова, Древняя и новая Россия Т. I. № 2 (1878) [Rovinskij P. A., Rossija i slavjane Balkanskogo poluostrova, Drevnajaja i novaja Rossija, T. I, № 2 (1878)]

Ровинский П. А., Сербская Морава, Вестник Европы, Кн. 4 (1876) [Rovinskij P. A., Serbskaja Morava, Vestnik Evropi, Kn. 4 (1876)]

Ровинский П. А., Сербская Морава, Русские о Сербии и сербах, Т. I. [Rovinskij P. А., Serbskaja Morava, Russkie o Serbii i serbah, T. I]

Ровинский П. А., Черногория в ее прошлом и настоящем, Т. І, Санкт-Петербург 1888; T. II, Ч. 1, Санкт-Петербург 1897; Т. II, Ч. 2, Санкт-Петербург 1901; Т. III, Петроград 1915. [Rovinskij P. A., Černogorija v ee prošlom i nastojaščem, T. I, Sankt-Peterburg 1888; T. II, Č. 1, Sankt-Petarburg 1897; T. II, Č. 2, Sankt-Peterburg 1901; T. III, Petrograd 1915] 
Стојановић К., Слом и васкрсење Србије, прир. С. Турлаков, Београд 2012. [Stojanović K., Slom i vaskrsenje Srbije, prir. S. Turlakov, Beograd 2012]

Тодорова М., Имагинарни Балкан, Београд 1999. [Todorova M., Imaginarni Balkan, Beograd 1999]

Шемякин А. Л., «Мир детства» сербов в путевых записках П.А. Ровинского, Славянский альманах, Москва 2004. [Šemjakin A. L., «Mir detstva» serbov v putevih zapiskah P. A. Rovinskogo, Slavjanskij almanah, Moskva 2004]

Шемякин А. Л., Павел Ровинский. Сербская физиономия Белграда, Родина, № 9 (Москва 2006) [Šemjakin A. L., Pavel Rovinskij. Serbskaja fizionomija Belgrada, Rodina, № 9 (Moskva 2006)]

Шнирельман В. А., Национальные символь, этноисторические мифы и этнополитика, Македония. Проблемы истории и культуры, Отв. ред. Р. П. Гришина, Москва 1999. [Šnirel'man V. A., Nacional'nie simvoli, etnoistoričeskie mifi i etnopolitika, Makedonija, Problemi istorii i kul'turi, Otv. red. R. P. Grišina, Moskva 1999]

Шнирельман В. А., Подделки и альтернативная история, Фальсификация исторических источников и конструирование этнократических мифов, Отв. ред. А. Е. Петров, В. А. Шнирельман, Москва 2011. [Šnirel'man V. A., Poddelki i al 'ternativnaja istorija, Fal'sifikacija istoričeskih istočnikov i konstruirovanie etnokratičeskih mifov, Otv. red. A. E. Petrov, V. A. Šnirel'man, Moskva 2011] 


\title{
Andrey L. SHEMYAKIN \\ SERBIAN WORKS OF P. A. ROVINSKY \\ (PREVIOUS EXAMINATIONS AND RESEARCH PERSPECTIVES)
}

\begin{abstract}
Summary
Even a perfunctory view of Serbian texts of Pavel Apolonovich Rovinsky shows their powerful information and analytical potential. The reliability of the author's conclusions is further amplified given the culture of his attitude towards his “craft”, i.e. his profession. Rovinsky's clear understanding of the complexity of a defined task (making a comprehensive picture out of details in the context of a systematic approach and delineating a complete "physiognomy" of the Serbs) made him set before himself a number of strict scientific and ethical requirements. He considered compliance with these requirements a mandatory condition for resolving a specific task, this being - the representative nature of selected sources for making generalisations, objectivity and absence of personal ambition: "I tried to inspect everything that was possible, I did not want to miss any subject, no matter how far it was from my personal objectives and views". Further on, in a form of a summary, he writes: "Resisting, as much as possible, any tendency [...], I can bravely claim that I treated everything in an impartial way, trying to transpose every phenomenon with the greatest possible accuracy".
\end{abstract}

Keywords: P. A. Rovinsky, Serbia, Europe, mentality of Serbian traditional society, imagology, modernisation.

Чланак примљен: 18. 12. 2017.

Чланак коначно прихваћен за објављивање: 01. 06. 2018. 